\title{
Relationship between serum total carbon dioxide concentration and bicarbonate concentration in patients undergoing hemodialysis
}

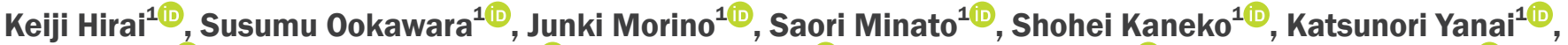

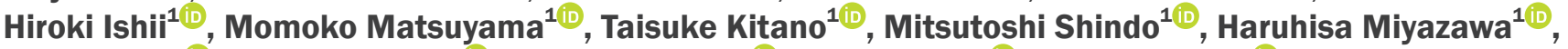

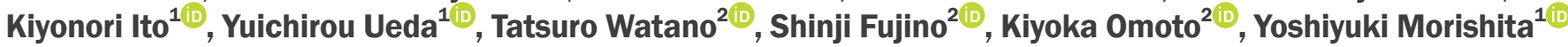 \\ 'Division of Nephrology, First Department of Integrated Medicine, Saitama Medical Center, Jichi Medical University, Saitama, Japan \\ ${ }^{2}$ Department of Laboratory Medicine, Saitama Medical Center, Jichi Medical University, Saitama, Japan
}

Background: Few studies have investigated the relationship between serum total carbon dioxide $\left(\mathrm{CO}_{2}\right)$ concentration and bicarbonate ion $\left(\mathrm{HCO}_{3}{ }^{-}\right.$) concentration in patients undergoing hemodialysis. We determined the agreement and discrepancy between serum total $\mathrm{CO}_{2}$ and $\mathrm{HCO}_{3}{ }^{-}$concentrations and the diagnostic accuracy of serum total $\mathrm{CO}_{2}$ for the prediction of low $\left(\mathrm{HCO}_{3}{ }^{-}<24 \mathrm{mEq} / \mathrm{L}\right)$ and high $\left(\mathrm{HCO}_{3}{ }^{-} \geq 24 \mathrm{mEq} / \mathrm{L}\right)$ bicarbonate concentrations in hemodialysis patients.

Methods: One hundred forty-nine arteriovenous blood samples from 84 hemodialysis patients were studied. Multiple linear regression analysis was used to determine factors correlated with $\mathrm{HCO}_{3}{ }^{-}$concentration. Diagnostic accuracy of serum total $\mathrm{CO}_{2}$ was evaluated using receiver operating characteristic curve analysis and a $2 \times 2$ table. Agreement between serum total $\mathrm{CO}_{2}$ and $\mathrm{HCO}_{3}{ }^{-}$concentrations was assessed using Bland-Altman analysis.

Results: Serum total $\mathrm{CO}_{2}$ concentration was closely correlated with $\mathrm{HCO}_{3}{ }^{-}$concentration $(\beta=0.858, P<0.001)$. Area under the curve of serum total $\mathrm{CO}_{2}$ for the identification of low and high bicarbonate concentrations was 0.989. Use of serum total $\mathrm{CO}_{2}$ to predict low and high bicarbonate concentrations had a sensitivity of $100 \%$, specificity of $50.0 \%$, positive predictive value of $96.5 \%$, negative predictive value of $100 \%$, and accuracy of $96.6 \%$. Bland-Altman analysis showed moderate agreement between serum total $\mathrm{CO}_{2}$ and $\mathrm{HCO}_{3}{ }^{-}$concentrations. Discrepancies between $\mathrm{HCO}_{3}{ }^{-}$and serum total $\mathrm{CO}_{2}$ concentrations (serum total $\mathrm{CO}_{2}-\mathrm{HCO}_{3}{ }^{-} \leq-1$ ) were observed in 89 samples.

Conclusion: Serum total $\mathrm{CO}_{2}$ concentration is closely correlated with $\mathrm{HCO}_{3}{ }^{-}$concentration in hemodialysis patients. However, there is a non-negligible discrepancy between serum total $\mathrm{CO}_{2}$ and $\mathrm{HCO}_{3}{ }^{-}$concentrations.

Keywords: Acid base balance, Bicarbonate, Hemodialysis, Serum total carbon dioxide

Received December 11, 2019; Revised June 22, 2020; Accepted June 22, 2020

Editor: Sejoong Kim, Seoul National University, Seongnam, Republic of Korea

Correspondence: Keiji Hirai

Division of Nephrology, First Department of Integrated Medicine, Saitama Medical Center, Jichi Medical University, 1-847 Amanuma-cho, Omiya-ku, Saitama-shi, Saitama-ken 330-8503, Japan. E-mail: keijihirai@kfy.biglobe.ne.jp

Copyright (C) 2020 by The Korean Society of Nephrology

(a) This is an open-access article distributed under the terms of the Creative Commons Attribution Non-Commercial License (http://creativecommons.org/ licenses/by-nc-nd/4.0/), which permits unrestricted non-commercial use, distribution, and reproduction in any medium, provided the original work is properly cited. 


\section{Introduction}

Metabolic acidosis is a commonly identified complication in patients undergoing hemodialysis, and it can contribute to bone mineral loss, protein energy wasting, cardiovascular disease, and higher mortality risk [1-4]. Therefore, early and accurate diagnosis of metabolic acidosis is important to prevent cardiovascular events and increases in the risk of mortality.

In Japan, blood-gas analyzers are available in most hospitals. Therefore, bicarbonate ion $\left(\mathrm{HCO}_{3}^{-}\right)$concentration, measured in arteriovenous blood samples, has been widely used to assess metabolic acidosis in hemodialysis patients [5]. Lower $\mathrm{HCO}_{3}{ }^{-}$concentration has been reported to be associated with higher risk of cardiac dysfunction, peripheral vascular disease, and death in patients undergoing hemodialysis $[6,7]$. Therefore, $\mathrm{HCO}_{3}{ }^{-}$is a significant predictor of cardiovascular disease and mortality in hemodialysis patients. However, these blood-gas analyses require a specific measuring device and syringe, in addition to blood samples used for these analyses [8].

Serum total carbon dioxide $\left(\mathrm{CO}_{2}\right)$ concentration can be readily measured, along with serum creatinine, urea, and electrolytes, using a biochemical analyzer in a clinical setting [9]. Furthermore, serum total $\mathrm{CO}_{2}$ has been shown to closely correlate with $\mathrm{HCO}_{3}{ }^{-}$concentration in patients with chronic kidney disease (CKD) who are not undergoing renal replacement therapy [10]. However, few studies have investigated the relationship between serum total $\mathrm{CO}_{2}$ and $\mathrm{HCO}_{3}{ }^{-}$concentrations in patients undergoing hemodialysis. Therefore, in the present study, we aimed to analyze the agreement between these two parameters in patients undergoing hemodialysis.

\section{Methods}

\section{Ethical approval of the study protocol}

This study was carried out in accordance with the ethical principles contained within the Declaration of Helsin$\mathrm{ki}$ and its subsequent amendments. The study protocol was approved by the Ethics Committee of Saitama Medical Center, Jichi Medical University (S17-052; Saitama, Japan). The requirement for informed consent was waived and an opt-out method was used due to the retrospective design of the study.

\section{Inclusion and exclusion criteria}

Inclusion criteria were: 1 ) age $>20$ years; 2) CKD stage G5D; and 3) simultaneous measurement of serum total $\mathrm{CO}_{2}$ and $\mathrm{HCO}_{3}^{-}$concentrations. Exclusion criteria were 1) peritoneal dialysis and 2) renal transplantation.

\section{Study design}

This was a single-center, retrospective, cross-sectional study. We analyzed patient data obtained from medical records at the Division of Nephrology, Saitama Medical Center, between April 2016 and March 2018. Laboratory data in the form of blood tests and blood-gas analyses that had been obtained simultaneously were analyzed.

Relationship between serum total $\mathrm{CO}_{2}$ and $\mathrm{HCO}_{3}^{-}$concentrations was analyzed using Pearson's correlation coefficient. Independent factors correlated with $\mathrm{HCO}_{3}{ }^{-}$ concentration were identified using multiple linear regression analysis. Diagnostic accuracy of serum total $\mathrm{CO}_{2}$ for the identification of low and high bicarbonate concentrations was analyzed using receiver operating characteristic (ROC) curve analysis and a $2 \times 2$ table. Agreement between serum total $\mathrm{CO}_{2}$ and $\mathrm{HCO}_{3}{ }^{-}$concentrations was analyzed using Bland-Altman analysis. Relationship between serum total $\mathrm{CO}_{2}$ concentrations measured using blood-gas analyses and an enzymatic method was analyzed using Pearson's correlation coefficient. Agreement of serum total $\mathrm{CO}_{2}$ concentrations between the bloodgas and enzymatic methods was evaluated using BlandAltman analysis.

\section{Laboratory methods}

Blood parameters were measured at the Department of Clinical Laboratory, Saitama Medical Center. Blood samples were obtained from an arteriovenous fistula just before the commencement of the first hemodialysis session in a week. Samples of arteriovenous blood were collected in ethylenediamine tetraacetic acid (EDTA)containing tubes from the arteriovenous fistula and centrifuged within 15 minutes to obtain serum. Serum total $\mathrm{CO}_{2}$ was measured within 15 minutes after centrifugation in an automated biochemical analyzer (JCA-BM6070; JEOL, Tokyo, Japan), as were biochemical parameters (hemoglobin, total protein, serum albumin, blood urea 
nitrogen, serum creatinine, sodium, potassium, chloride, calcium, phosphate, magnesium, and glucose). Serum total $\mathrm{CO}_{2}$ was determined by an enzymatic method using a commercial kit (Toyobo, Osaka, Japan) in an automated biochemical analyzer. Serum total $\mathrm{CO}_{2}$ was measured by monitoring the oxidation of nicotinamide adenine dinucleotide (NADH) at $405 \mathrm{~nm}$ using the coupled assay of phosphoenolpyruvate carboxylase and malate dehydrogenase. The decrease in NADH concentration is proportional to the concentration of serum total $\mathrm{CO}_{2}$ in the sample, allowing measurement of serum total $\mathrm{CO}_{2}$ concentration [9]. Single-pool Kt/V was calculated using the formula of Daugirdas [11].

Samples of arteriovenous blood for gas analyses were collected in a heparinized blood-gas syringe from the arteriovenous fistula at the same time samples were collected for other blood tests, and analyzed within $10 \mathrm{~min}$ utes to obtain the $\mathrm{pH}$ value and partial pressure of carbon dioxide $\left(\mathrm{pCO}_{2}\right)$. The $\mathrm{pH}$ and $\mathrm{pCO}_{2}$ of blood were measured using a blood-gas analyzer (Rapidlab-1265; Siemens Healthcare Diagnostics, Tarrytown, NY, USA). $\mathrm{HCO}_{3}{ }^{-}$ concentration was calculated from the measured $\mathrm{pH}$ and

Table 1. Patient characteristics and medications

\begin{tabular}{lc}
\hline \multicolumn{1}{c}{ Characteristic } & Value \\
\hline Number of patients & 84 \\
Number of samples & 149 \\
Age (yr) & $67.1 \pm 11.5$ \\
Sex (male) & $61(72.6)$ \\
Body mass index $\left(\mathrm{kg} / \mathrm{m}^{2}\right)$ & $22.1 \pm 3.9$ \\
Hemodialysis duration (mo) & $15.5(3.7-38.8)$ \\
Diabetes mellitus & $53(63.1)$ \\
Corticosteroid & $11(13.1)$ \\
$\beta$-blocker & $38(45.2)$ \\
Renin-angiotensin system inhibitor & $44(52.4)$ \\
Aldosterone receptor antagonist & $1(1.2)$ \\
Loop diuretic & $45(53.6)$ \\
Thiazide diuretic & $18(21.4)$ \\
Potassium binder & $7(8.3)$ \\
Phosphate binder & $49(58.3)$ \\
Calcium-containing phosphate binder & $31(36.9)$ \\
Calcium-free phosphate binder & $34(40.5)$ \\
Vitamin D analog & $43(51.2)$ \\
Cinacalcet & $11(13.1)$ \\
Single pool Kt/V & $1.3(1.0-1.5)$ \\
\hline
\end{tabular}

Data are presented as number only, mean \pm standard deviation, number (\%), or median (interquartile range).
$\mathrm{pCO}_{2}$ using the Henderson-Hasselbalch equation [12]:

$$
\mathrm{pH}=6.1+\log \left(\left[\mathrm{HCO}_{3}^{-}\right] / \mathrm{pCO}_{2} \times 0.03\right) .
$$

\section{Statistical analyses}

Statistical analyses were performed using JMP ver. 11 (SAS Institute, Cary, NC, USA). Continuous variables with a normal distribution were expressed as means \pm standard deviations while those with a non-normal distribution were expressed as medians and interquartile ranges. Categorical variables were expressed as numbers and percentages. Hemodialysis duration and single pool Kt/V were not normally distributed; therefore, these valuables were transformed using the natural logarithm. Relationships between two variables were evaluated using Pearson's correlation coefficient. Linear regression analysis was used to identify parameters that were independently correlated with $\mathrm{HCO}_{3}{ }^{-}$concentration. Linearities between dependent and independent variables were examined using spline analysis, and linear relationships were found between $\mathrm{HCO}_{3}^{-}$concentration and the other variables. Parameters that were significantly correlated with $\mathrm{HCO}_{3}{ }^{-}$concentration in simple linear regression analyses were included in a subsequent multiple linear regression analysis. Multi-collinearity was examined by calculating variance inflation factors for all the independent variables; no multi-collinearity was detected for any of these variables. Diagnostic accuracy of serum total $\mathrm{CO}_{2}$ was determined using ROC curve analysis and a $2 \times 2$ table. Area

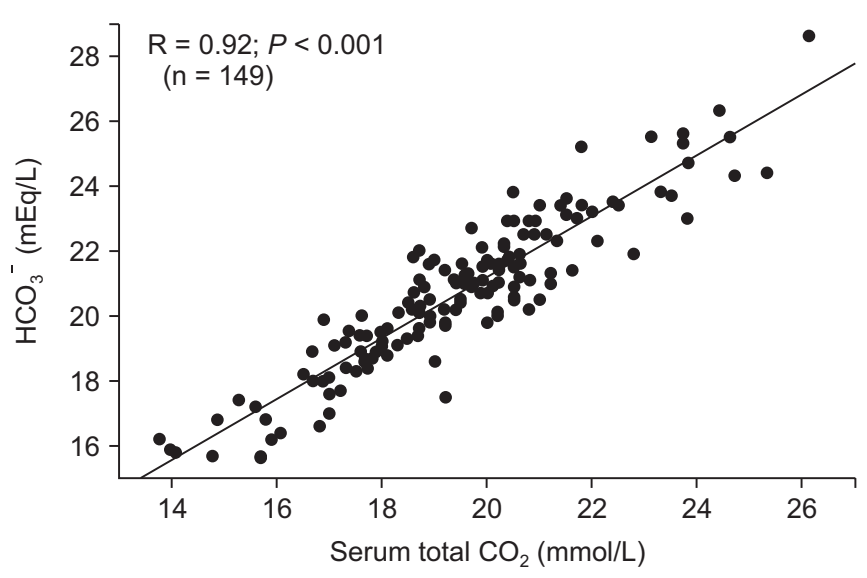

Figure 1. Relationship between serum total $\mathrm{CO}_{2}$ and $\mathrm{HCO}_{3}{ }^{-}$ concentration.

$\mathrm{CO}_{2}$, carbon dioxide; $\mathrm{HCO}_{3}{ }^{-}$, bicarbonate ion. 
under the curve (AUC), sensitivity, specificity, positive predictive value, negative predictive value, and accuracy were calculated for the identification of low $\left(\mathrm{HCO}_{3}{ }^{-}<24 \mathrm{mEq} / \mathrm{L}\right)$ and high $\left(\mathrm{HCO}_{3}^{-} \geq 24 \mathrm{mEq} / \mathrm{L}\right)$ bicarbonate concentrations based on the cut-off value for $\mathrm{HCO}_{3}{ }^{-}$of $24 \mathrm{mEq} / \mathrm{L}$ established in a previous study [3]. Agreement between serum total $\mathrm{CO}_{2}$ and $\mathrm{HCO}_{3}{ }^{-}$concentrations was assessed using the Bland-Altman method. $P<0.05$ was considered to indicate statistical significance.

\section{Results}

\section{Patient characteristics}

Characteristics of the patients and their medications are shown in Table 1. A total of 149 blood samples from 84 patients (61 males and 23 females; mean age: $67.1 \pm 11.5$ years; body mass index: $22.1 \pm 3.9 \mathrm{~kg} / \mathrm{m}^{2}$ ) were obtained. Mean single pool Kt/V was $1.3(1.0-1.5)$ and $63.1 \%$ of the participants had diabetes mellitus. Proportions of par-

Table 2. Simple and multiple linear regression analyses of parameters correlated with $\mathrm{HCO}_{3}{ }^{-}$concentration

\begin{tabular}{|c|c|c|c|c|}
\hline \multirow[t]{2}{*}{ Parameter } & \multicolumn{2}{|c|}{ Simple linear regression analysis } & \multicolumn{2}{|c|}{$\begin{array}{l}\text { Multivariate linear regression analysis using } \\
\text { variables with } P<0.05 \text { in univariate analyses }\end{array}$} \\
\hline & Standard coefficient & $P$ value & Standard coefficient & $P$ value \\
\hline Sex (male: yes or no) & -0.119 & 0.15 & & \\
\hline Body mass index $\left(\mathrm{kg} / \mathrm{m}^{2}\right)$ & -0.138 & 0.09 & & \\
\hline Ln-hemodialysis duration (mo) & -0.054 & 0.52 & & \\
\hline Corticosteroid (yes or no) & 0.068 & 0.41 & & \\
\hline$\beta$-blocker (yes or no) & 0.018 & 0.83 & & \\
\hline Renin-angiotensin system inhibitor (yes or no) & -0.171 & 0.04 & 0.038 & 0.26 \\
\hline Aldosterone receptor antagonist (yes or no) & -0.143 & 0.08 & & \\
\hline Loop diuretic (yes or no) & 0.007 & 0.93 & & \\
\hline Calcium-containing phosphate binder (yes or no) & -0.006 & 0.95 & & \\
\hline Calcium-free phosphate binder (yes or no) & -0.010 & 0.90 & & \\
\hline Vitamin D analogue (yes or no) & -0.030 & 0.72 & & \\
\hline Cinacalcet (yes or no) & -0.000 & 1.00 & & \\
\hline Ln-single pool Kt/V & 0.059 & 0.48 & & \\
\hline Total protein $(\mathrm{g} / \mathrm{dL})$ & 0.052 & 0.53 & & \\
\hline Serum albumin (g/dL) & -0.061 & 0.46 & & \\
\hline Hemoglobin (g/dL) & -0.192 & 0.02 & -0.037 & 0.33 \\
\hline Blood urea nitrogen $(\mathrm{mg} / \mathrm{dL})$ & -0.148 & 0.07 & & \\
\hline Phosphate (mg/dL) & -0.285 & $<0.001$ & -0.024 & 0.49 \\
\hline Magnesium (mg/dL) & 0.084 & 0.31 & & \\
\hline Blood glucose (mg/dL) & -0.035 & 0.67 & & \\
\hline Serum total $\mathrm{CO}_{2}(\mathrm{mmol} / \mathrm{L})$ & 0.922 & $<0.001$ & 0.858 & $<0.001$ \\
\hline
\end{tabular}

$\mathrm{HCO}_{3}^{-}$, bicarbonate ion; Ln, logarithm. 
ticipants taking various medications were as follows: corticosteroid, 13.1\%; $\beta$-blocker, $45.2 \%$; renin-angiotensin system inhibitor, $52.4 \%$; aldosterone receptor antagonist, $1.2 \%$; loop diuretic, $53.6 \%$; thiazide diuretic, $21.4 \%$; potassium binder, $8.3 \%$; phosphate binder, $58.3 \%$; calciumcontaining phosphate binder, $36.9 \%$; calcium-free phosphate binder, $40.5 \%$; vitamin $\mathrm{D}$ analogue, $51.2 \%$; and cinacalcet, $13.1 \%$.

\section{Relationship between serum total $\mathrm{CO}_{2}$ and $\mathrm{HCO}_{3}^{-}$ concentrations}

Fig. 1 shows the correlation between serum total $\mathrm{CO}_{2}$ and $\mathrm{HCO}_{3}{ }^{-}$concentrations. Serum total $\mathrm{CO}_{2}$ concentration was correlated closely with $\mathrm{HCO}_{3}{ }^{-}$concentration $(\mathrm{r}=$ 0.92; $P<0.001)$. Serum total $\mathrm{CO}_{2}$ level was also correlated closely with blood-gas total $\mathrm{CO}_{2}$ concentration $(\mathrm{r}=0.92 ; P<$ $0.001)$.

\section{Factors associated with $\mathrm{HCO}_{3}^{-}$concentration}

Simple linear regression analyses showed that $\mathrm{HCO}_{3}{ }^{-}$ concentration was significantly negatively correlated with hemoglobin, creatinine, chloride, and phosphate concentrations, and with the use of a renin-angiotensin system inhibitor. $\mathrm{HCO}_{3}{ }^{-}$concentration was significantly positively correlated with serum total calcium and total $\mathrm{CO}_{2}$. A multiple linear regression analysis was performed using variables that showed significant correlations with

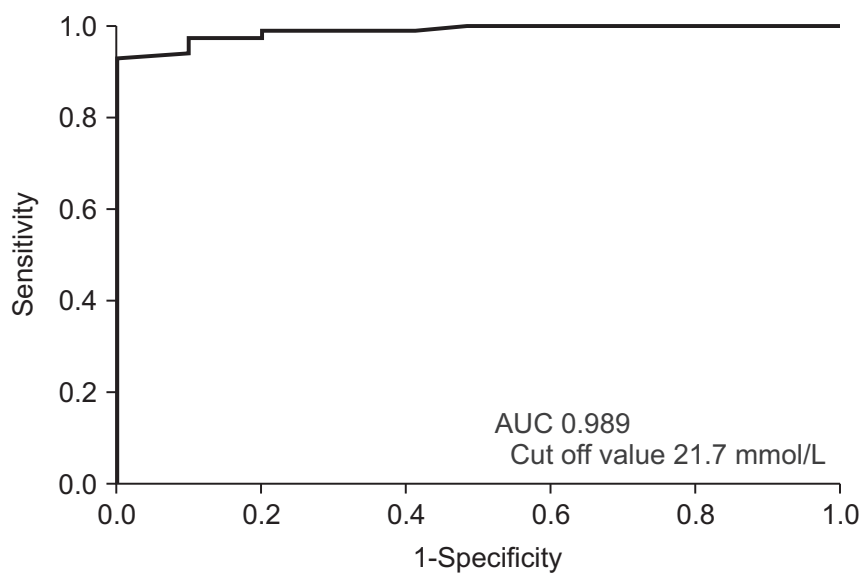

Figure 2. Receiver operating characteristic curve of serum total $\mathrm{CO}_{2}$ for the identification of low $\left(\mathrm{HCO}_{3}{ }^{-}<24 \mathrm{mEq} / \mathrm{L}\right)$ and high $\left(\mathrm{HCO}_{3}{ }^{-} \geq 24 \mathrm{mEq} / \mathrm{L}\right.$ ) bicarbonate concentrations.

$\mathrm{AUC}$, area under the curve; $\mathrm{CO}_{2}$, carbon dioxide; $\mathrm{HCO}_{3}{ }^{-}$, bicarbonate ion.
$\mathrm{HCO}_{3}{ }^{-}$concentration in simple linear regression analyses (Table 2). This analysis revealed that chloride (standard coefficient $[\beta]=-0.087, P=0.009)$, total calcium $(\beta=$ $0.133, P<0.001)$, and serum total $\mathrm{CO}_{2}(\beta=0.858, P<0.001)$ were independently correlated with $\mathrm{HCO}_{3}{ }^{-}$concentration.

Diagnostic accuracy of serum total $\mathrm{CO}_{2}$ for the prediction of low and high bicarbonate concentrations

The serum total $\mathrm{CO}_{2}$ ROC curve for the identification of low $\left(\mathrm{HCO}_{3}{ }^{-}<24 \mathrm{mEq} / \mathrm{L}\right)$ and high $\left(\mathrm{HCO}_{3}{ }^{-} \geq 24 \mathrm{mEq} / \mathrm{L}\right)$ bicarbonate concentrations is shown in Fig. 2. The AUC was 0.989 , and the optimal cut-off value was $21.7 \mathrm{mmol} /$ L. The $2 \times 2$ tables, stratified according to serum total $\mathrm{CO}_{2}$ and $\mathrm{HCO}_{3}{ }^{-}$concentrations for low and high bicarbonate groups, are shown in Table 3. The diagnostic accuracy measures of serum total $\mathrm{CO}_{2}$ for the prediction of low and high bicarbonate concentrations were as follows: sensitivity (99.3\%), specificity (50.0\%), positive predictive value $(96.5 \%)$, negative predictive value $(83.3 \%)$, accuracy $(96.0 \%)$, pre-test probability (93.3\%), positive post-test probability (96.5\%), and negative post-test probability (16.7\%).

\section{Agreement between serum total $\mathrm{CO}_{2}$ and $\mathrm{HCO}_{3}^{-}$ concentrations}

Bland-Altman analysis showed a moderate agreement between serum total $\mathrm{CO}_{2}$ and $\mathrm{HCO}_{3}{ }^{-}$concentrations. Mean difference was $-1.24 \pm 0.92$, and more than $95 \%$ of the points were included within the limits of agreement

Table 3. $2 \times 2$ tables stratified according to serum total $\mathrm{CO}_{2}$ and $\mathrm{HCO}_{3}{ }^{-}$concentration for low and high bicarbonate samples

\begin{tabular}{|c|c|c|c|}
\hline & \multicolumn{2}{|c|}{$\mathrm{HCO}_{3}^{-}$} & \multirow[b]{2}{*}{ Total } \\
\hline & $\begin{array}{c}\text { Low bicarbonate } \\
\left(\mathrm{HCO}_{3}^{-}<24 \mathrm{mEq} / \mathrm{L}\right)\end{array}$ & $\begin{array}{l}\text { High bicarbonate } \\
\left(\mathrm{HCO}_{3}^{-} \geq 24 \mathrm{mEq} / \mathrm{L}\right)\end{array}$ & \\
\hline \multicolumn{4}{|l|}{ Serum total $\mathrm{CO}_{2}$} \\
\hline $\begin{array}{l}\text { Low serum total } \mathrm{CO}_{2} \\
\text { (Serum total } \mathrm{CO}_{2}< \\
24 \mathrm{mmol} / \mathrm{L} \text { ) }\end{array}$ & 138 & 5 & 143 \\
\hline $\begin{array}{l}\text { High serum total } \mathrm{CO}_{2} \\
\text { (Serum total } \mathrm{CO}_{2} \geq \\
24 \mathrm{mmol} / \mathrm{L} \text { ) }\end{array}$ & 1 & 5 & 6 \\
\hline Total & 139 & 10 & 149 \\
\hline
\end{tabular}

$\mathrm{CO}_{2}$, carbon dioxide; $\mathrm{HCO}_{3}^{-}$, bicarbonate ion. 
A Serum total $\mathrm{CO}_{2}$ and $\mathrm{HCO}_{3}{ }^{-}$concentration

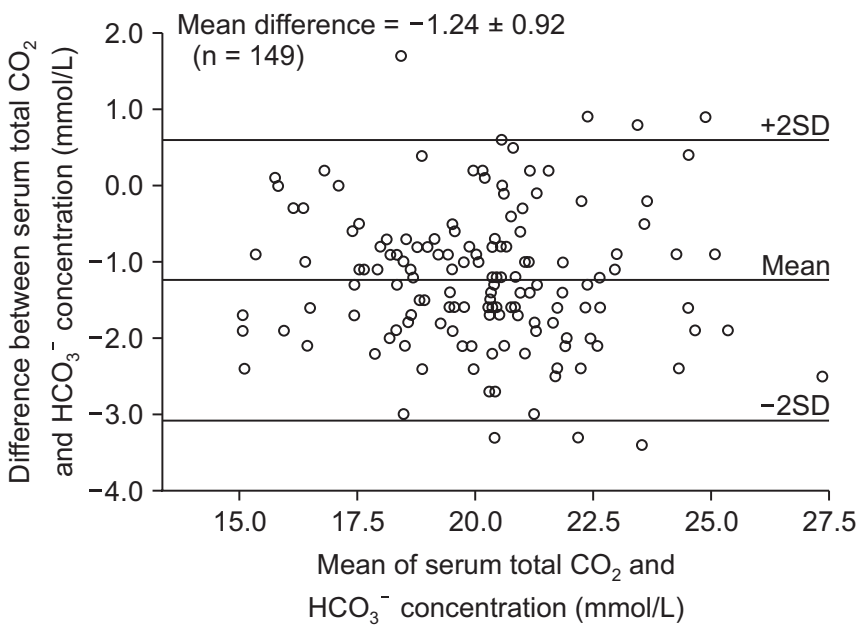

B Serum total $\mathrm{CO}_{2}$ and blood-gas total $\mathrm{CO}_{2}$ concentration

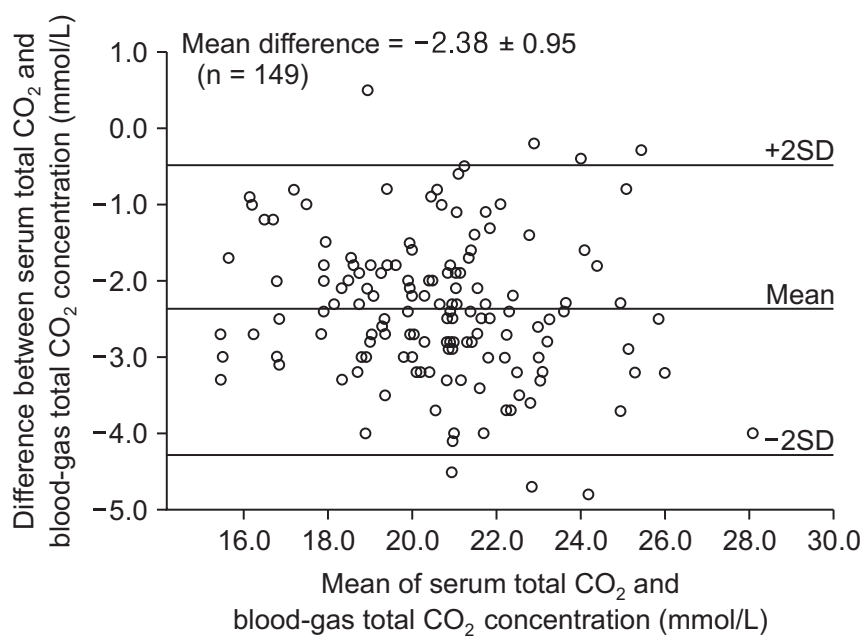

Figure 3. Bland-Altman analyses of the agreement between serum total $\mathrm{CO}_{2}$ and $\mathrm{HCO}_{3}{ }^{-}$concentration, and between serum total $\mathrm{CO}_{2}$ and blood-gas total $\mathrm{CO}_{2}$ concentration. (A) Bland-Altman plot comparing serum total $\mathrm{CO}_{2}$ and $\mathrm{HCO}_{3}{ }^{-}$Concentration. (B) BlandAltman plot comparing serum total $\mathrm{CO}_{2}$ and blood-gas total $\mathrm{CO}_{2}$ concentration.

$\mathrm{CO}_{2}$, carbon dioxide; $\mathrm{HCO}_{3}^{-}$, bicarbonate ion; $\mathrm{SD}$, standard deviation.

Table 4. Comparison of acid-base balance parameters among groups divided according to the difference between serum total $\mathrm{CO}_{2}$ and $\mathrm{HCO}_{3}{ }^{-}$concentration

\begin{tabular}{|c|c|c|c|}
\hline & $\begin{array}{c}\text { Serum total } \mathrm{CO}_{2}<\mathrm{HCO}_{3}^{-} \\
\text {(serum total } \mathrm{CO}_{2}-\mathrm{HCO}_{3}^{-} \leq-1 \text { ) }\end{array}$ & $\begin{array}{c}\text { Serum total } \mathrm{CO}_{2}=\mathrm{HCO}_{3}^{-} \\
\left(-1<\text { serum total } \mathrm{CO} 2-\mathrm{HCO}_{3}^{-}<1\right)\end{array}$ & $\begin{array}{c}\text { Serum total } \mathrm{CO} 2>\mathrm{HCO}_{3}^{-} \\
\text {(serum total } \mathrm{CO} 2-\mathrm{HCO}_{3}^{-} \geq 1 \text { ) }\end{array}$ \\
\hline Number of samples & 89 & 59 & 1 \\
\hline Serum total $\mathrm{CO}_{2}(\mathrm{mmol} / \mathrm{L})$ & 19.2 & 19.7 & 19.2 \\
\hline Blood-gas total $\mathrm{CO}_{2}(\mathrm{mmol} / \mathrm{L})$ & $22.2^{*}$ & 21.3 & 18.7 \\
\hline $\mathrm{HCO}_{3}^{-}(\mathrm{mEq} / \mathrm{L})$ & $21.0 *$ & 20.1 & 17.5 \\
\hline $\mathrm{pCO}_{2}(\mathrm{mmHg})$ & $37.6 *$ & 36.4 & 39.0 \\
\hline $\mathrm{pH}$ & 7.37 & 7.36 & 7.27 \\
\hline
\end{tabular}

$\mathrm{CO}_{2}$, carbon dioxide; $\mathrm{HCO}_{3}^{-}$, bicarbonate ion; $\mathrm{pCO}_{2}$, partial pressure of carbon dioxide.

$* P<0.05$ vs. the serum total $\mathrm{CO}_{2}=\mathrm{HCO}_{3}{ }^{-}$group.

(mean difference between the two methods \pm 2 standard deviations) (Fig. 3A). This analysis also showed a moderate agreement between serum total $\mathrm{CO}_{2}$ and blood-gas total $\mathrm{CO}_{2}$ concentrations. The mean difference was $-2.38 \pm 0.95$, and more than $95 \%$ of the points were included within the limits of agreement (mean difference between the two methods \pm 2 standard deviations) (Fig. 3B). Additionally, we divided the samples into three groups according to the difference between serum total $\mathrm{CO}_{2}$ and $\mathrm{HCO}_{3}{ }^{-}$ concentrations: serum total $\mathrm{CO}_{2}<\mathrm{HCO}_{3}^{-}$(serum total $\left.\mathrm{CO}_{2}-\mathrm{HCO}_{3}^{-} \leq-1\right)$, serum total $\mathrm{CO}_{2}=\mathrm{HCO}_{3}^{-}(-1<$ serum total $\mathrm{CO}_{2}-\mathrm{HCO}_{3}^{-}<1$ ), and serum total $\mathrm{CO}_{2}>\mathrm{HCO}_{3}^{-}$ (serum total $\mathrm{CO}_{2}-\mathrm{HCO}_{3}^{-} \geq 1$ ). The number of samples in each group were 89, 59, and 1, respectively (Table 4). $\mathrm{HCO}_{3}{ }^{-}$, blood-gas total $\mathrm{CO}_{2}$, and $\mathrm{pCO}_{2}$ were significantly higher in the serum total $\mathrm{CO}_{2}<\mathrm{HCO}_{3}{ }^{-}$group than in the serum total $\mathrm{CO}_{2}=\mathrm{HCO}_{3}{ }^{-}$group $($each $P<0.05)$.

\section{Discussion}

In the present study, we assessed the relationship between serum total $\mathrm{CO}_{2}$ and $\mathrm{HCO}_{3}{ }^{-}$concentrations in hemodialysis patients, and found that serum total $\mathrm{CO}_{2}$ concentration was closely correlated with $\mathrm{HCO}_{3}{ }^{-}$concentration. We also found that serum total $\mathrm{CO}_{2}$ concentration had high diagnostic accuracy for the prediction of low and high bicarbonate concentrations in hemodialysis patients.

"Serum total $\mathrm{CO}_{2}$ " is the total concentration of all forms of $\mathrm{CO}_{2}$ in a serum sample, which includes $\mathrm{HCO}_{3}{ }^{-}$, car- 
bonate, and dissolved $\mathrm{CO}_{2}$. In general, serum total $\mathrm{CO}_{2}$ is approximately equivalent to the $\mathrm{HCO}_{3}{ }^{-}$concentration, because most $\mathrm{CO}_{2}$ exists as $\mathrm{HCO}_{3}{ }^{-}$in the blood [9]. Furthermore, serum total $\mathrm{CO}_{2}$ has been reported to be closely correlated with $\mathrm{HCO}_{3}{ }^{-}$concentration in pre-dialysis CKD patients [10]. However, a discrepancy between serum total $\mathrm{CO}_{2}$ and $\mathrm{HCO}_{3}{ }^{-}$concentration, caused by differences in temperature and/or acidity [13], is sometimes identified in patients without renal impairment [14]. In the present study, calcium and chloride concentrations, in addition to serum $\mathrm{CO}_{2}$, were independently correlated with $\mathrm{HCO}_{3}{ }^{-}$concentration in serum. $\mathrm{HCO}_{3}{ }^{-}$ concentration was reported to be negatively correlated with calcium concentration in CKD stage G5D patients [15]. However, $\mathrm{HCO}_{3}{ }^{-}$concentration was positively correlated with calcium concentration in the present study. This discrepancy might be explained by the fact that $\sim 50 \%$ of the participants in the present study had been taking a calcium-containing phosphate binder, which has been reported to be positively associated with $\mathrm{HCO}_{3}^{-}$ concentration [16] $\mathrm{HCO}_{3}{ }^{-}$concentration is known to decrease as chloride concentration increases because of the equilibrium between $\mathrm{HCl}$ and $\mathrm{NaHCO}_{3}: \mathrm{H}^{+}+\mathrm{Cl}^{-}+\mathrm{Na}^{+}+$ $\mathrm{HCO}_{3}{ }^{-}=\mathrm{Na}^{+}+\mathrm{Cl}^{-}+\mathrm{H}_{2} \mathrm{CO}_{3}[17]$. In the present study, chloride concentration was negatively correlated with $\mathrm{HCO}_{3}{ }^{-}$ concentration, which is compatible with the findings of a previous study [10]. Correlations between calcium or chloride and $\mathrm{HCO}_{3}{ }^{-}$concentration were weak, but significant. Serum total $\mathrm{CO}_{2}$ was closely correlated with $\mathrm{HCO}_{3}{ }^{-}$ concentration and showed a high level of accuracy for the diagnosis of high or low bicarbonate concentrations. Therefore, serum $\mathrm{CO}_{2}$ may represent a useful predictor of bicarbonate concentration and whether this is high or low. In our study, arteriovenous blood samples were analyzed. Serum total $\mathrm{CO}_{2}$ has been reported to correlate strongly with $\mathrm{HCO}_{3}{ }^{-}$concentration in both arterial and venous blod samples $[10,18]$. Arterial $\mathrm{pCO}_{2}$ and $\mathrm{HCO}_{3}{ }^{-}$ concentration have been shown to correlate strongly with venous $\mathrm{pCO}_{2}$ and $\mathrm{HCO}_{3}{ }^{-}$concentration, respectively [19]. In the present study, serum total $\mathrm{CO}_{2}$ showed a close correlation with $\mathrm{HCO}_{3}{ }^{-}$concentration in arteriovenous blood samples, which are a mixture of arterial and venous blood. These results suggest that serum total $\mathrm{CO}_{2}$ is closely correlated with $\mathrm{HCO}_{3}{ }^{-}$concentration in arteriovenous blood samples. Further studies are needed to confirm the correlation between serum total $\mathrm{CO}_{2}$ and
$\mathrm{HCO}_{3}{ }^{-}$concentrations measured in arteriovenous blood samples in hemodialysis patients.

It has been reported that serum albumin, estimated glomerular filtration rate, and blood glucose are independently correlated with $\mathrm{HCO}_{3}{ }^{-}$concentration, in addition to serum total $\mathrm{CO}_{2}$, in $\mathrm{CKD}$ patients not undergoing renal replacement therapy [10]. There are several potential explanations for the differences between our results and those previously published. First, a higher serum albumin concentration has been shown to be associated with metabolic acidosis in pre-dialysis CKD patients [20], and this phenomenon is considered to be at least in part due to the weak acidity of albumin [21]. Loss of albumin into the dialysate and its adsorption onto the dialysis membrane can occur during hemodialysis [22]. Influx of $\mathrm{HCO}_{3}{ }^{-}$from the dialysate into the blood occurs during hemodialysis because the $\mathrm{HCO}_{3}{ }^{-}$concentration in serum is usually lower than that in the dialysate [4]. Therefore, the reduction in serum albumin due to loss into the dialysate and adsorption onto the dialysis membrane, and the increase in $\mathrm{HCO}_{3}{ }^{-}$caused by influx from the dialysate into the blood, might affect the relationship between serum albumin and $\mathrm{HCO}_{3}{ }^{-}$in hemodialysis patients. Second, serum $\mathrm{HCO}_{3}{ }^{-}$concentration has been reported to decrease as renal function decreases in pre-dialysis CKD patients, and this reduction is considered to be due to the inability of the kidney to synthesize ammonia, regenerate $\mathrm{HCO}_{3}{ }^{-}$, and excrete hydrogen ions $\left(\mathrm{H}^{+}\right)[23]$. An increase in urinary glucose as a result of hyperglycemia has been shown to inhibit the excretion of $\mathrm{H}^{+}$through the proximal renal tubules via the sodium-glucose-coupled transporter, with consequent inhibition of the $\mathrm{Na}^{+}-\mathrm{H}^{+}$exchanger because of competition with sodium influx [24,25]. The participants in the present study had been undergoing hemodialysis for a mean of 46.6 months, suggesting that they had little residual renal function [26]. Therefore, loss of residual renal function might explain the lack of correlation between serum creatinine or blood glucose and $\mathrm{HCO}_{3}{ }^{-}$concentration in the study.

Serum total $\mathrm{CO}_{2}$ is usually higher than $\mathrm{HCO}_{3}{ }^{-}$concentration because total $\mathrm{CO}_{2}$ is equal to the sum of the $\mathrm{HCO}_{3}{ }^{-}$ concentration and dissolved $\mathrm{CO}_{2}$, which is calculated from $\mathrm{pCO}_{2}$ [9]. However, in the present study, $\mathrm{HCO}_{3}{ }^{-}$ concentration was higher than serum total $\mathrm{CO}_{2}$ concentration in more than half of the patients. $\mathrm{PCO}_{2}$ value was higher in the serum total $\mathrm{CO}_{2}<\mathrm{HCO}_{3}{ }^{-}$group than the 
serum total $\mathrm{CO}_{2}=\mathrm{HCO}_{3}{ }^{-}$group. It has been reported that elevated $\mathrm{pCO}_{2}$ could cause a discrepancy between serum total $\mathrm{CO}_{2}$ and $\mathrm{HCO}_{3}{ }^{-}$concentration [14]. Another study reported that $\mathrm{HCO}_{3}{ }^{-}$concentration could be overestimated through a change in $\mathrm{pK}$ value caused by elevated $\mathrm{pCO}_{2}$ [8]. These findings might explain the discrepancy between serum total $\mathrm{CO}_{2}$ and $\mathrm{HCO}_{3}^{-}$concentration in our study. We found a discrepancy in serum total $\mathrm{CO}_{2}$ concentrations between blood-gas analyses and an enzymatic method, despite the fact that they were significantly correlated. Blood-gas analyzers measure $\mathrm{pH}$ and $\mathrm{pCO}_{2}$, and then calculate $\mathrm{HCO}_{3}^{-}$concentration using the Henderson-Hasselbalch equation. Subsequently serum total $\mathrm{CO}_{2}$ is calculated as $\mathrm{HCO}_{3}^{-}+0.03 \times \mathrm{pCO}_{2}$ [27]. By contrast, the enzymatic method measures $\mathrm{CO}_{2}$ released from plasma as a result of the addition of acid. This method measures the $\mathrm{CO}_{2}$ present as $\mathrm{HCO}_{3}{ }^{-}$, dissolved $\mathrm{CO}_{2}$, and carbamino $\mathrm{CO}_{2}$ [9]. Differences in measurement principles might explain the discrepancy in serum total $\mathrm{CO}_{2}$ concentrations between blood gas analyses and the enzymatic method. In the present study, the proportion of samples with a high bicarbonate concentration $\left(\mathrm{HCO}_{3}{ }^{-} \geq\right.$ $24 \mathrm{mEq} / \mathrm{L}$ ) was substantially lower than that reported in a previous study (6.7\% vs. 30\%) [3]. There are several possible explanations for this discrepancy. First, mean single pool Kt/V in our study was lower than that recommended by clinical practice guidelines [28]. Second, dialysate $\mathrm{HCO}_{3}{ }^{-}$concentrations differ among countries. Dialysate $\mathrm{HCO}_{3}{ }^{-}$concentration in hemodialysis is lower in Japan than in other countries [4]. Indeed, a trans nation-wide observational study showed that pre-dialysis $\mathrm{HCO}_{3}{ }^{-}$concentration was lowest in Japan among the seven countries that participated in the study [5]. Further studies are required to confirm the correlation between serum total $\mathrm{CO}_{2}$ and $\mathrm{HCO}_{3}{ }^{-}$concentrations in hemodialysis patients treated with increased dialysis efficiency and higher dialysate $\mathrm{HCO}_{3}^{-}$concentrations.

Measurement of serum total $\mathrm{CO}_{2}$ has two main advantages over blood-gas analyses. First, there is no need for a blood gas-syringe, which decreases costs, and the amount of blood that needs to be collected is less for serum total $\mathrm{CO}_{2}$ measurement than for blood gas measurements. Second, serum total $\mathrm{CO}_{2}$ can be used to predict low and high bicarbonate concentrations without the need for a blood-gas analyzer. Therefore, measurement of serum total $\mathrm{CO}_{2}$ can alleviate some of the burden on patients and laboratory staff.

Our study had four main limitations. First, it was a single-center, retrospective, observational study, and may therefore have been subject to patient selection bias. Second, the study cohort was small, especially patients with high $\mathrm{HCO}_{3}{ }^{-}$concentrations, which restricts the generalizability of our findings and assessment of the correlation between serum total $\mathrm{CO}_{2}$ and $\mathrm{HCO}_{3}^{-}$concentrations in patients with a high $\mathrm{HCO}_{3}^{-}$concentration. Third, we used arteriovenous blood samples for analyses; the results might have been different if arterial blood samples had been used. Fourth, hemodialysis duration varied widely among patients in the present study. Because residual renal function declines in accordance with increasing duration of dialysis, $\mathrm{HCO}_{3}{ }^{-}$concentration decreases as dialysis duration increases [29]. Therefore, the large variation in hemodialysis duration might have affected our study results by causing variation in $\mathrm{HCO}_{3}{ }^{-}$concentrations. Therefore, further prospective, large-scale, multicenter studies with an adequate number of patients with a high $\mathrm{HCO}_{3}{ }^{-}$concentration are required to confirm our findings. In conclusion, serum total $\mathrm{CO}_{2}$ concentration was closely correlated with $\mathrm{HCO}_{3}{ }^{-}$concentration in hemodialysis patients. However, there was a non-negligible discrepancy between serum total $\mathrm{CO}_{2}$ and $\mathrm{HCO}_{3}^{-}$concentrations.

\section{Conflicts of interest}

All authors have no conflicts of interest to declare.

\section{Acknowledgments}

We thank all the staff of the Department of Clinical Laboratory (Saitama Medical Center, Jichi Medical University, Saitama, Japan) for their excellent work. We also thank Mark Cleasby, PhD, from the Edanz Group (www. edanzediting.com/ac) for editing a draft of this manuscript.

\section{Authors' contributions}

Keiji Hirai and Susumu Ookawara conceived and designed the research. Keiji Hirai, Junki Morino, Momoko Matsuyama, Haruhisa Miyazawa, Kiyonori Ito, and Yuichirou Ueda performed research. Saori Minato, Shohei 
Kaneko, Katsunori Yanai, Hiroki Ishii, Taisuke Kitano, and Mitsutoshi Shindo collected the data. Keiji Hirai, Tatsuro Watano, Shinji Fujino, and Kiyoka Omoto performed the analysis. Keiji Hirai and Susumu Ookawara wrote the paper. Yoshiyuki Morishita made critical revisions and approved the final version. All authors read and approved the final manuscript.

\section{References}

[1] Lefebvre A, de Vernejoul MC, Gueris J, Goldfarb B, Graulet AM, Morieux C. Optimal correction of acidosis changes progression of dialysis osteodystrophy. Kidney Int 1989;36: 1112-1118.

[2] May RC, Kelly RA, Mitch WE. Mechanisms for defects in muscle protein metabolism in rats with chronic uremia. Influence of metabolic acidosis. J Clin Invest 1987;79:10991103.

[3] Vashistha T, Kalantar-Zadeh K, Molnar MZ, Torlén K, Mehrotra R. Dialysis modality and correction of uremic metabolic acidosis: relationship with all-cause and causespecific mortality. Clin J Am Soc Nephrol 2013;8:254-264.

[4] Tentori F, Karaboyas A, Robinson BM, et al. Association of dialysate bicarbonate concentration with mortality in the Dialysis Outcomes and Practice Patterns Study (DOPPS). Am J Kidney Dis 2013;62:738-746.

[5] Bommer J, Locatelli F, Satayathum S, et al. Association of predialysis serum bicarbonate levels with risk of mortality and hospitalization in the Dialysis Outcomes and Practice Patterns Study (DOPPS). Am J Kidney Dis 2004;44:661-671.

[6] Raikou VD, Kyriaki D. Association between low serum bicarbonate concentrations and cardiovascular disease in patients in the end-stage of renal disease. Diseases 2016;4:36.

[7] Raikou VD, Kyriaki D. Mortality and low serum bicarbonate level in patients on hemodiafiltration versus peritoneal dialysis. Indian J Nephrol 2018;28:105-112.

[8] O'Leary TD, Langton SR. Calculated bicarbonate or total carbon dioxide? Clin Chem 1989;35:1697-1700.

[9] Dobson GP, Veech RL, Hoeger U, Passonneau JV. Enzymatic determination of total CO2 in freeze-clamped animal tissues and plasma. Anal Biochem 1991;195:232-237.

[10] Hirai K, Minato S, Kaneko S, et al. Approximation of bicarbonate concentration using serum total carbon dioxide concentration in patients with non-dialysis chronic kidney disease. Kidney Res Clin Pract 2019;38:326-335.

[11] Daugirdas JT. Second generation logarithmic estimates of single-pool variable volume Kt/V: an analysis of error. J Am Soc Nephrol 1993;4:1205-1213.

[12] Ramsay AG. Clinical application of the Henderson-Hasselbalch equation. Appl Ther 1965;7:730-736.

[13] Maas AH, van Heijst AN, Visser BF. The determination of the true equilibrium constant $(\mathrm{pK} 1 \mathrm{~g})$ and the practical equilibrium coefficient ( $\mathrm{pK} 1 \mathrm{~g}$ ) for the first ionization of carbonic acid in solutions of sodium bicarbonate, cerebrospinal fluid, plasma and serum at 25 and 38. Clin Chim Acta 1971;33:325-343.

[14] Kim Y, Massie L, Murata GH, Tzamaloukas AH. Discrepancy between measured serum total carbon dioxide content and bicarbonate concentration calculated from arterial blood gases. Cureus 2015; 7:e398.

[15] Kaku Y, Ookawara S, Miyazawa H, et al. Approximation of corrected calcium concentrations in advanced chronic kidney disease patients with or without dialysis therapy. Nephron Extra 2015;5:39-49.

[16] Kasimatis E, Maksich D, Jassal V, Bargman JM, Oreopoulos DG. Predictive factors of low HCO3- levels in peritoneal dialysis patients. Clin Nephrol 2005;63:290-296.

[17] Nagami GT. Hyperchloremia - why and how. Nefrologia 2016;36:347-353.

[18] Kumar V, Karon BS. Comparison of measured and calculated bicarbonate values. Clin Chem 2008;54:1586-1587.

[19] Treger R, Pirouz S, Kamangar N, Corry D. Agreement between central venous and arterial blood gas measurements in the intensive care unit. Clin J Am Soc Nephrol 2010;5:3 90-394.

[20] Raphael KL, Zhang Y, Ying J, Greene T. Prevalence of and risk factors for reduced serum bicarbonate in chronic kidney disease. Nephrology (Carlton) 2014;19:648-654.

[21] Rossing TH, Maffeo N, Fencl V. Acid-base effects of altering plasma protein concentration in human blood in vitro. $J$ Appl Physiol (1985) 1986;61:2260-2265.

[22] van Gelder MK, Abrahams AC, Joles JA, Kaysen GA, Gerritsen KGF. Albumin handling in different hemodialysis modalities. Nephrol Dial Transplant 2018;33:906-913.

[23] Yaqoob MM. Acidosis and progression of chronic kidney disease. Curr Opin Nephrol Hypertens 2010;19:489-492.

[24] Nascimento-Gomes G, Mello-Aires M. Effect of glucose on the kinetics of bicarbonate reabsorption in the early and middle proximal tubule. Braz J Med Biol Res 1990;23:79-85.

[25] Lang F, Messner G, Rehwald W. Electrophysiology of sodium-coupled transport in proximal renal tubules. Am J Physiol 1986;250(6 Pt 2):F953-F962. 
[26] Lang SM, Bergner A, Töpfer M, Schiffl H. Preservation of residual renal function in dialysis patients: effects of dialysistechnique-related factors. Perit Dial Int 2001;21:52-57.

[27] Bulucu F, Çakar M, Kurt Ö, Yeşildal F, Şarlak H. Blood total carbon dioxide content and bicarbonate can be used together to predict blood $\mathrm{pH}$ correctly in venous blood samples. Ren Fail 2014;36:145-146.
[28] National Kidney Foundation. KDOQI Clinical Practice Guideline for Hemodialysis Adequacy: 2015 update. Am J Kidney Dis 2015;66:884-930.

[29] Liu XY, Gao XM, Zhang N, et al. Oral bicarbonate slows decline of residual renal function in peritoneal dialysis patients. Kidney Blood Press Res 2017;42:565-574. 